\title{
In a case of female-to-male sex reassignment, testosterone therapy switches on an underlying Brugada
}

\author{
Patrizia Vivona ${ }^{1,2}$, Federica Dagradi $^{3}$ and Michele M. Ciulla ${ }^{1,2^{*}}$ (])
}

\begin{abstract}
Background: The Brugada syndrome, diagnosed by a typical electrocardiographic pattern, is a genetic condition characterised by an increased risk of potentially lethal ventricular arrhythmias and sudden cardiac death. Even if its pathophysiological mechanism is unknown, its prevalence in male suggested a possible hormonal involvement.

Case presentation: In this case involving a woman who underwent a female-to-male sex reassignment, we documented that testosterone administration was able to switch on and, when stopped, to switch off a latent pattern of Brugada.

Conclusions: Our observation strongly supports a possible involvement of testosterone in the ECG manifestation of Brugada syndrome even if the general low prevalence of the Brugada syndrome does not support to screen every female-to-male sex reassignment.
\end{abstract}

Keywords: Brugada syndrome, Testosterone, Sex change

\section{Introduction}

Sex change is a dramatic and controversial procedure that allows anatomical, legal, and psychosocial adaptations to another gender. Hormonal treatments are administered as a part of the procedures for sex reassignment and, in a female-to-male reassignment, include a testosterone preparation and a possible testosterone maintenance [1]. In theory, the hormonal changes over time could alter the cardiovascular risk profile related to the different gender, even if it appears to be rather safe in the short and medium term, as a study seems to suggest [2]. Unfortunately, there are no data in the literature on the possibility that a latent pathological phenotype can be, eventually, switched on by testosterone therapy. In this regard, we

\footnotetext{
*Correspondence: michele.ciulla@unimi.it

1 Laboratory of Clinical Informatics and Cardiovascular Imaging,

Department of Clinical Sciences and Community Health, University of Milan, Milan, Italy

Full list of author information is available at the end of the article
}

know that the Brugada syndrome, recognised since 1992, occurs in males about 8-10 times more than in women [3]; thus, a possible hormonal involvement might play a role. Currently, the diagnosis is based on the detection of a typical electrocardiographic pattern (type 1). Furthermore, there are twelve known genes potentially responsible for the condition [4], and all genotypes correlate with alterations of cardiac action potential determined by a decrease in inward sodium or calcium currents, or an increase in outward potassium currents. Although there are some publications $[4,5]$ connecting the hormonal influence with the evidence of arrhythmias and Brugada syndrome, here we present a case report that, for the first time, supports a direct connection between androgen therapy and the Brugada pattern switch-on. This case is about a young woman who underwent a sex change and, after she started a testosterone-based therapy, she manifested a typical Brugada pattern on ECG.

(c) The Author(s) 2020. This article is licensed under a Creative Commons Attribution 4.0 International License, which permits use, sharing, adaptation, distribution and reproduction in any medium or format, as long as you give appropriate credit to the original author(s) and the source, provide a link to the Creative Commons licence, and indicate if changes were made. The images or other third party material in this article are included in the article's Creative Commons licence, unless indicated otherwise in a credit line to the material. If material is not included in the article's Creative Commons licence and your intended use is not permitted by statutory regulation or exceeds the permitted use, you will need to obtain permission directly from the copyright holder. To view a copy of this licence, visit http://creativeco mmons.org/licenses/by/4.0/. 


\section{Case}

In a 30-year-old woman admitted to gynaecology for a sex change, an ECG was obtained and a Brugada syndrome was suspected. Previous ECGs were normal. She took testosterone for about a year. In a subsequent ECG performed during a routine cardiological visit, it was evident a 1-mm ST segment elevation in V2 lead. She was, therefore, referred to our Center of Genetic Heart Disease and Arrhythmias. She had not have family history of sudden death and she denied syncope in her personal history, but palpitations were reported when assuming testosterone. A dosage of plasma testosterone and a 24-hour Holter ECG were obtained. Thereafter, a flecainide test was performed unmasking a typical ECG pattern of Brugada (Fig. 1). Genetic tests were negative for mutations related to SCN5A [6], the gene coding for the $\alpha$-subunit of the most abundant sodium channel in the heart; after momentary suspension of testosterone, the ECG no longer showed a Brugada pattern. When the hormone was reintroduced, the Brugada pattern reappeared on the ECG alone with the same episodes of palpitation, while major arrhythmias were never documented. Original ambulatory ECG tracings done during the follow-up are shown in Fig. 2.

\section{Discussion}

The pathophysiological mechanism for Brugada syndrome is essentially unknown. The debate whether Brugada syndrome is linked to heart depolarisation or repolarisation is still open. The identification of mutations in the genes encoding the sodium channels, suggests a disturbance of the depolarisation; for a long time, it was thought that at the base of the pathophysiological mechanism was the impaired depolarisation localised in the right ventricular outflow tract level, due to a mismatch between the transient outward potassium current Ito and the sodium current depolarising (INa). The right ventricular outflow tract is the area considered as the arrhythmogenic substrate of the disease because it presents different characteristics of the distribution of ion channels, compared to the other parts of the heart, already present in the embryonic life that persist into the

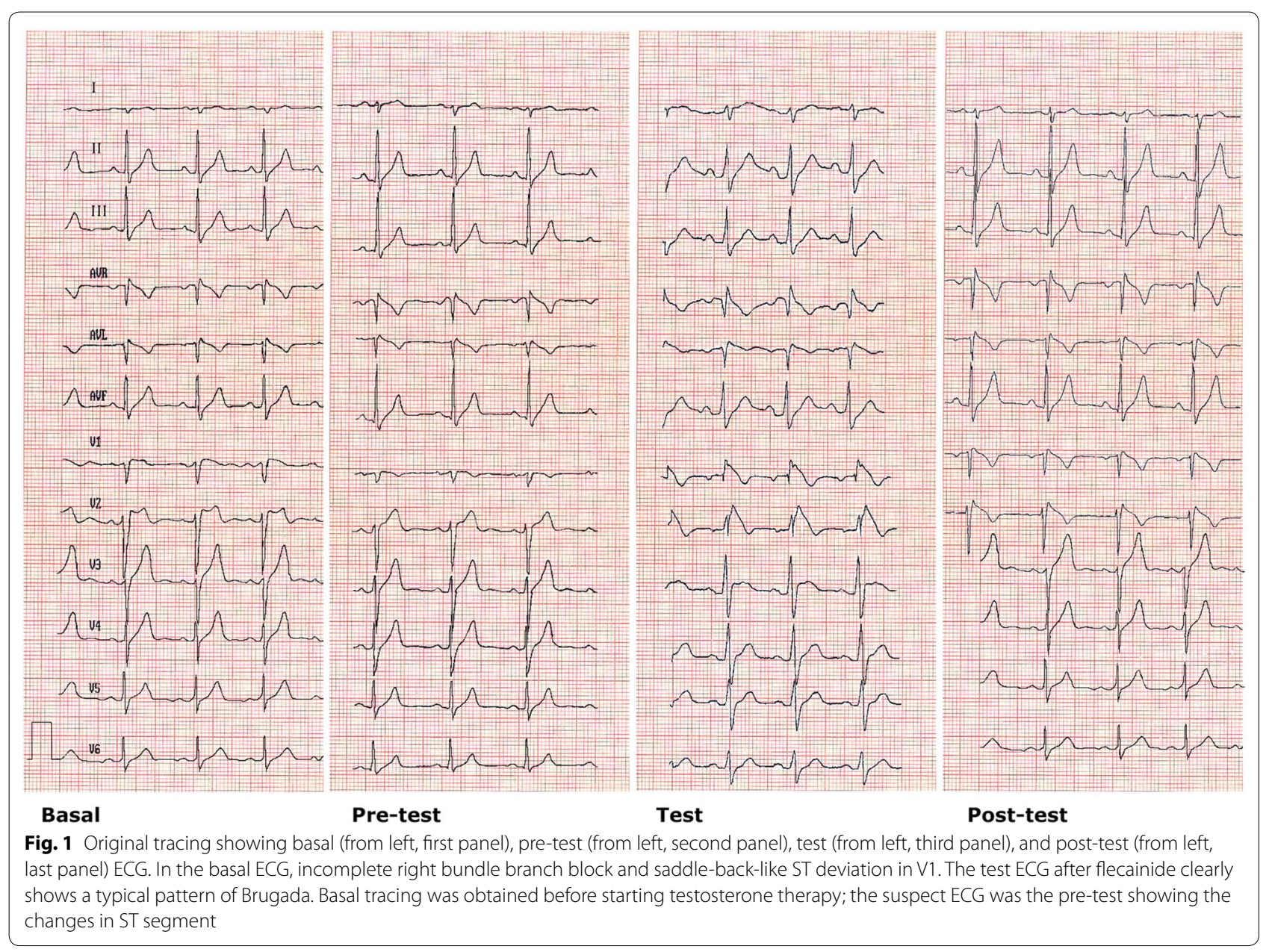




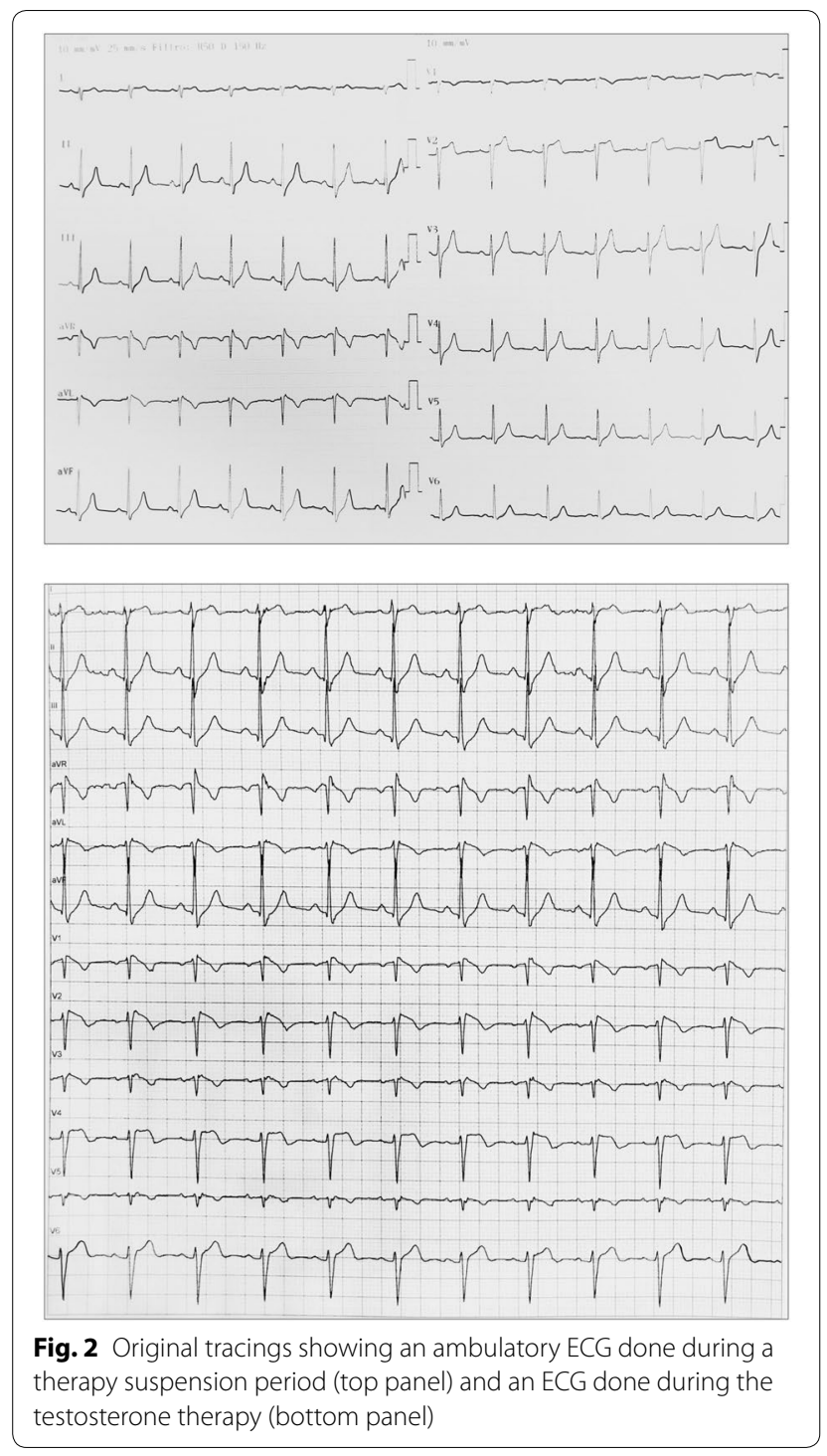

adult life. One experimental study in dogs demonstrates that transmural difference in $\mathrm{INa}$ in female was reduced to values observed in male by testosterone [7]. If these results could suggest to hypothesise that INa dispersion is modulated by testosterone, this could be an important factor supporting gender differences in myocytes action potential duration dispersion and arrhythmias; similarly, we might assume that the same could happen on cardiomyocytes of a woman who is taking androgens.

\section{Conclusion}

A woman that undergoes a sex change is usually pretreated with testosterone aiming at the virilisation of traits, including a deepening of the voice, the production of male-pattern body hair, growth and physical contours, and cessation of menses. In our case, as we have clearly demonstrated by an appropriate test, the androgen administration/cessation was able to switch on and off a latent pattern of Brugada. Due to the general low prevalence of the Brugada syndrome our observation does not support to screen every female-to-male sex reassignment. On the contrary, it strongly supports a possible involvement of testosterone in ion channelopathies like the Brugada syndrome [8-10]. However, it will be prudent to offer a baseline ECG in preparation for the administration of testosterone in order to prevent the rise of a fatal syndrome.

\section{Abbreviations}

ECG: electrocardiogram; SCN5A: sodium channel, voltage-gated, type V, alpha subunit; laNa: late sodium current depolarising.

\section{Authors' contributions}

Each author contributed equally. All authors read and approved the final manuscript.

\section{Availability of supporting data}

Since it is a single case report, only clinical records were available.

\section{Consent for publication}

A consent form for anonymous publication of clinical data was obtained.

\section{Competing interests}

Not applicable.

\section{Author details}

${ }^{1}$ Laboratory of Clinical Informatics and Cardiovascular Imaging, Department of Clinical Sciences and Community Health, University of Milan, Milan, Italy. ${ }^{2}$ Department of Clinical Sciences and Community Health, University of Milan, Milan, Italy. ${ }^{3}$ Istituto Auxologico Italiano, IRCCS, Center for Cardiac, Arrhythmia of Genetic Origin, Milan, Italy.

Received: 21 January 2020 Accepted: 2 October 2020

Published online: 19 October 2020

\section{References}

1. Petering RC, Brooks NA. Testosterone therapy: review of clinical applications. Am Fam Phys. 2017;96(7):441-9.

2. Gooren LJ, Giltay EJ, Bunck MC. Long-term treatment of transsexuals with cross-sex hormones: extensive personal experience. J Clin Endocrinol Metab. 2008;93(1):19-25.

3. Priori SG, Wilde AA, Horie M, Cho Y, Behr ER, Berul C, Blom N, Brugada J, Chiang CE, Huikuri H, Kannankeril P, Krahn A, Leenhardt A, Moss A, Schwartz PJ, Shimizu W, Tomaselli G, Tracy C. Executive summary: HRS/ EHRA/APHRS expert consensus statement on the diagnosis and management of patients with inherited primary arrhythmia syndromes. Heart Rhythm. 2013;10(12):e85-108.

4. Crotti L, Marcou CA, Tester DJ, Castelletti S, Giudicessi JR, Torchio M, Medeiros-Domingo A, Simone S, Will ML, Dagradi F, Schwartz PJ, Ackerman MJ. Spectrum and prevalence of mutations involving Br S1-through BrS12-susceptibility genes in a cohort of unrelated patients referred for Brugada syndrome genetic testing: implications for genetic testing. J Am Coll Cardiol. 2012;60(15):1410-8.

5. Yamaki M, Sato N, Okada M, Fujita S, Go K, Sakamoto N, Tanabe Y, Takeuchi T, Kawamura Y, Hasebe N. A case of Brugada syndrome in which diurnal ECG changes were associated with circadian rhythms of sex hormones. Int Heart J. 2009;50(5):669-76.

6. Matsuo K, Akahoshi M, Seto S, Yano K. Disappearance of the Brugadatype electrocardiogram after surgical castration: a role for testosterone 
and an explanation for the male preponderance. Pacing Clin Electrophysiol. 2003;26(7 Pt 1):1551-3.

7. Cerrone M, Remme CA, Tadros R, Bezzina CR, Delmar M. Beyond the one gene-one disease paradigm: complex genetics and pleiotropy in inheritable cardiac disorders. Circulation. 2019;140(7):595-610.

8. Barajas-Martinez H, Haufe V, Chamberland C, Roy MJ, Fecteau MH, Cordeiro JM, Dumaine R. Larger dispersion of INa in female dog ventricle as a mechanism for gender-specific incidence of cardiac arrhythmias. Cardiovasc Res. 2009:81(1):82-9.

9. Çatakoğlu AB, Kendirci M. Testosterone replacement therapy and cardiovascular events. Turk Kardiyol Dern Ars. 2017;45(7):664-72.
10. Benito B, Berruezo A. Brugada syndrome and pregnancy: delving into the role of sex hormones in ion channelopathies. Rev Esp Cardiol. 2014;67(3):165-7.

\section{Publisher's Note}

Springer Nature remains neutral with regard to jurisdictional claims in published maps and institutional affiliations.
Ready to submit your research? Choose BMC and benefit from:

- fast, convenient online submission

- thorough peer review by experienced researchers in your field

- rapid publication on acceptance

- support for research data, including large and complex data types

- gold Open Access which fosters wider collaboration and increased citations

- maximum visibility for your research: over $100 \mathrm{M}$ website views per year

At BMC, research is always in progress.

Learn more biomedcentral.com/submissions 